\title{
Religious Rhetoric and the Evolution of George W. Bush's Political Philosophy
}

\author{
LAUREN FRANCES TUREK
}

This essay surveys George W. Bush's public statements from 1993 to $200 \mathrm{I}$ to examine the evolution of his religious and political rhetoric. Bush's personal religiosity and his use of religious rhetoric during his campaigns for the presidency and in his two terms in office have received extensive comment from the press as well as from scholars. Yet very little scholarly work has considered the role of religion in his earlier political career. Although Bush had evinced a deep and genuine evangelical faith for years before he launched his bid for the governorship, he did not begin his political career as an overtly Christian leader. Instead, over the course of his governorship, he gradually incorporated Christian tropes in his speeches to develop, explain, and gain support for his "compassionate conservative" policies and to build rapport with voters.

On the evening of i I September 200 I, President George W. Bush addressed a shocked and grieving nation, asking the public to pray for the victims who had perished in the terrorist attacks of that morning. After quoting Psalm 23, he resolved to stand strong in the face of global terrorism and called on all Americans to "go forward to defend freedom and all that is good and just in our world." The rhetorical links that Bush drew in this speech between freedom, justice, and faith (in American strength and in God) presaged the foreign policy agenda that came to define his two terms in office. ${ }^{2}$ Given the melding of religious and political values often associated with his presidency, Bush's call

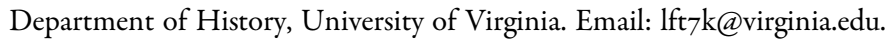

The author would like to thank Melvyn P. Leffler, Brian Rosenwald, Molly Scudder, Christina Simko, and the two anonymous readers for the Journal of American Studies for their invaluable feedback and suggestions.

${ }^{\text {I }}$ George W. Bush, "Address by George W. Bush, President of the United States, Delivered to the Nation, Washington, D. C., September I, 2001," in Vital Speeches of the Day, Volume LXVII, no. 24 (New York: The City News Pub. Co., I Oct. 200I). President Bush quoted the first part of Psalm 23:4 "Even though I walk through the valley of the shadow of death, I fear no evil, for You are with me."

${ }^{2}$ Bush described this agenda broadly as seeking "the end of tyranny in our world" by spreading democracy abroad, which he believed would ensure greater security and allow the American nation to control its "destiny." George W. Bush, "Address before a Joint Session of the Congress on the State of the Union," 3 I Jan. 2006. 
to prayer and action on 9/I I seems neither noteworthy nor surprising. Yet the events of I I September 200 I fundamentally altered the toolbox of religious tropes that George Bush drew from when expressing his political philosophy; there is no evidence that Bush held messianic views about America's role in the world during his time campaigning for or serving as governor of Texas. ${ }^{3}$ Indeed, his personal piety notwithstanding, Bush seemed reticent to discuss religion in the early years of his governorship. ${ }^{4}$ Rather, as the values that shaped his "compassionate conservative" agenda became increasingly appealing to voters between 1993 and 200I, Bush grew more accustomed to referencing his Christian faith to build and consolidate political support. Although the terrorist attacks transformed Bush's vision for America and the religious themes he employed to marshal support for his foreign policy, his use of religious rhetoric to frame his policy agenda reflected the evolving significance that religion had in the development of his political career. This evolution, which corresponded with broader shifts in the US cultural and political landscape of the mid- to late I990s, is critical for contextualizing the salience of evangelical rhetoric in George W. Bush's presidential campaigns and in his presidency.

Bush's personal religiosity and use of religious rhetoric during his campaigns for the presidency and in his two terms in office have received extensive comment from the press as well as from political scientists, historians, and other

${ }^{3}$ A number of authors have argued that $9 /$ i I transformed Bush's foreign-policy vision and, therefore, the way in which he and his speechwriters talked about American engagements abroad. Citing Jim Wallis, D. Jason Berggren and Nicol C. Rae state that "the terrorist attacks in New York and Washington transformed Bush from the lamb into the lion, from 'self-help Methodist' to 'a messianic Calvinist," and suggest that "he believes that September I I has called him to lead the country to a new calling." D. J. Berggren and N. C. Rae, "Jimmy Carter and George W. Bush: Faith, Foreign Policy, and an Evangelical Presidential Style," Presidential Studies Quarterly, 36, 4 (Dec. 2006), 606-32, 620; Jim Wallis, "Dangerous Religion: George W. Bush's Theology of Empire,” Sojourners (Sept.-Oct. 2003), 20-26. See also David Aikman, A Man of Faith: The Spiritual Journey of George W. Bush (Nashville, TN: W Publishing Group, 2004), 162-63, 171-73; Gary Scott Smith, Faith and the Presidency: From George Washington to George W. Bush (New York: Oxford University Press, 2006), 397-98; Stephen Mansfield, The Faith of George W. Bush (New York: Penguin, 2003), 136; Nancy Gibbs and John F. Dickerson, "Celebration and Dissent," Time, 165, 5 (3 I Jan. 2005), 38-39; Frank Bruni, Ambling into History: the Unlikely Odyssey of George W. Bush (New York: HarperCollins, 2002), 256-59. Rogers M. Smith argues that after 9/ I I Bush more frequently used and placed greater emphasis on providential themes in his speeches than previous Presidents had when discussing their policy agendas. Rogers M. Smith, "Religious Rhetoric and the Ethics of Public Discourse: The Case of George W. Bush," Political Theory, 36, (Apr. 2008), 272-300, 280, 282-83, 285.

${ }^{4}$ This, and his perceived political moderation, led some observers to question whether or not the religious right would support him as a potential presidential nominee for the 2000 election. See Sam Howe Verhovek, "Is There Room on the Republican Ticket for Another Bush?" New York Times Magazine, i 3 Sept. 1998, 8. 
scholars. Much of this literature is biographical in nature, tracing the familiar story of Bush's spiritual awakening in the 1980 s and drawing connections between his evangelical faith and the types of policy and the political connections he developed while President. 5 Yet even the more critical evaluations of George W. Bush's political career tend not to address the ways in which religion shaped his tenure and legislative agenda as governor of Texas. ${ }^{6}$ This is a crucial oversight. Although Bush gained some political experience through his failed 1978 congressional campaign and as an informal aide and liaison to the Christian right during George H.W. Bush's 1988 presidential bid, he did not begin to forge an effective personal political identity or leadership style until his successful campaigns for, and time as, governor. Indeed, Bush's viability as a presidential candidate derived, in part, from the political capital and national visibility he built through the legislative successes of his governorship. As such, examining the ways in which Bush utilized-or, at times, eschewed - religious language and moral justifications for his decision-making as a governor sheds considerable light on how and why he adopted overtly evangelical rhetoric while running for and serving as president.

Assessing George W. Bush's evolving use of religious rhetoric also illuminates the challenges that Republicans faced in attempting to balance the competing agendas of social and economic conservatives as the party returned to and sought to hold Congressional (and later executive) power in the mid- to

'For a selection of works that assess or discuss the relationship between Bush's faith and his political leadership see Peter Singer, The President of Good and Evil: The Ethics of George W. Bush (New York: Dutton, 2004); James L. Guth, "George W. Bush and Religious Politics," in Steven E. Schier, ed., High Risk and Big Ambition: The Presidency of George $W$. Bush (Pittsburgh: University of Pittsburgh Press, 2004), 117-4I; Joseph M. Knippenberg, "The Personal Is (Not?) the Political: The Role of Religion in the Presidency of George W. Bush," in Ronald L. Weed and John von Heyking, eds., Civil Religion in Political Thought: Its Perennial Questions and Enduring Relevance in North America (Washington, DC: Catholic University of America Press, 2010), 262-79; Aikman; Gary Scott Smith, 368-71; Mansfield.

${ }^{6}$ For example, in his excellent chapter on religion and the George W. Bush presidency, historian Kevin Kruse notes that Bush entered the campaign for President seeking to put "a kinder, gentler face" on conservatism, and noted that the fact that "his faith formed an essential part of both his private character and his public persona" made him particularly well suited to this task. Kruse does not, however, address how Bush had developed that outwardly religious public (and political) persona during his governorship; he simply states that he employed this persona to good effect in building connections with key constituent groups while campaigning for the presidency. See Kevin M. Kruse, "Compassionate Conservatism: Religion in the Age of George W. Bush," in Julian E. Zelizer, ed., The Presidency of George W. Bush: A First Historical Assessment (Princeton: Princeton University Press, 2010), 229. Likewise, in his analysis of Bush's governorship, Brian McCall offers little in the way of discussion about how Bush drew on religion to shape his legislative agenda in Texas. Brian McCall, The Power of the Texas Governor: Connally to Bush (Austin: University of Texas Press, 2009). 
late I990s. Although he cultivated close ties with the religious right during his presidential campaigns, Bush often prioritized economic policy over conservative social issues once in office. ${ }^{7}$ Nevertheless, his identification with the Christian right remained strong throughout his presidency, and the compassionate conservative political philosophy that he espoused enabled him to appeal to the interests of a wide range of conservative and independent voters. ${ }^{8}$ Exploring how Bush employed religious rhetoric to navigate the fault lines within his party illustrates the latent fragility and disunity of late twentieth-century conservatism, a topic which historian Julian Zelizer suggests represents a potential "third wave of historical scholarship on modern conservatism."9 At the same time, the Republican revolution of 1994 and George W. Bush's election as President speaks to the durability of conservative ideology and the power of grassroots Christian and conservative organizing to shape the political discourse of the nation. Examining the manner in which Bush adapted his rhetoric and political persona to suit the changing needs of the Republican Party, in Texas as well as nationally, is key to understanding

${ }^{7}$ John W. Wells and David B. Cohen, "Keeping the Charge: George W. Bush, the Christian Right, and the New Vital Center of American Politics," in Mark J. Rozell and Gleaves Whitney, eds., Religion and the Bush Presidency (New York: Palgrave Macmillan, 2007), I 29-54, I 47-48.

${ }^{8}$ Ibid. Political scientists Wells and Cohen argue that "Bush has used the social issues agenda of the Christian Right to facilitate a kind of triangulation in American politics," in order to enhance the appeal of the Republican party to moderate and independent voters and thus attempt to build a "big-tent" party.

9 Julian E. Zelizer, "Reflections: Rethinking the History of American Conservatism," Reviews in American History, 38, 2 (June 2010), 367-92, 387. Briefly, Zelizer posits that the first wave of scholarship on conservatism focussed on the elite, intellectual history of the movement and the second wave on grassroots conservative activism. For major works of the first wave see George H. Nash, The Conservative Intellectual Movement in America since 1945 (New York: Basic Books, 1976); as well as the more recent Patrick Allit, The Conservatives: Ideas and Personalities throughout American History (New Haven: Yale University Press, 2009). On the second wave see Lisa McGirr, Suburban Warriors: The Origins of the New American Right (Princeton: Princeton University Press, 200I); Matthew D. Lassiter, The Silent Majority: Suburban Politics in the Sunbelt South (Princeton: Princeton University Press, 2005); Kevin M. Kruse, White Flight: Atlanta and the Making of Modern Conservatism (Princeton: Princeton University Press, 2007); Donald T. Critchlow, The Conservative Ascendancy: How the GOP Right Made Political History (Cambridge, MA: Harvard University Press, 2007). For recent work that might be included in the new third wave see David T. Courtwright, No Right Turn: Conservative Politics in a Liberal America (Cambridge, MA: Harvard University Press, 2010). Select literature on the rise of the religious right as part of the conservative ascendancy includes William C. Martin, With God on Our Side: The Rise of the Religious Right in America (New York: Broadway Books, 1996); Paul Boyer, "The Evangelical Resurgence in I970s American Protestantism," in Bruce J. Schulman and Julian E. Zelizer, eds., Rightward Bound: Making America Conservative in the 1970s (Cambridge, MA: Harvard University Press, 2008), 29-5 I; Darren Dochuk, From Bible Belt to Sunbelt: Plain-folk Religion, Grassroots Politics, and the Rise of Evangelical Conservatism (New York: W. W. Norton, $20 \mathrm{II}$ ). 
not only his use of religious language as President, but the nature of American conservatism at the turn of the twenty-first century as well.

When George W. Bush announced his candidacy for the governorship of Texas in 1993, his evangelical faith received little, if any, discussion in the press. Between the formal declaration of his intention to run against Democratic incumbent Ann Richards on 8 November 1993 and his victory in the election one year later, Bush rarely even mentioned religion. He focussed instead on four core issues: education, welfare reform, juvenile crime, and tort reform. ${ }^{\circ} \mathrm{He}$ called for independence for local school districts to enable them to set their own education standards "and release them from what he call[ed] 'burdensome state regulations." "' Hewing to conservative lines, Bush expressed concern about high taxes, dependency on welfare, and the growth of the state government. ${ }^{12}$ In particular, he emphasized his vision for instilling more personal accountability in Texas, which he planned to foster by slashing welfare and creating harsher punishments for criminals. As one journalist noted, "the kind of government Bush says he prefers is one that creates 'negative reinforcement' to make people change their behavior." '3 Bush campaigned on a platform of change, distinguishing himself from Governor Richards, whom he criticized for supporting "big government, increased spending and centralized control by government bureaucracy." ${ }^{14} \mathrm{His}$ issue-drive campaign did not rely on, or utilize, religious rhetoric to win over voters. Despite Richards's popularity among Texas voters, and her challenger's lack of political experience, Bush and Richards remained neck and neck throughout the campaign.

Still, in early 1994, divisions emerged within the Texas GOP over issues of interest to the religious right that had the potential to threaten Bush's political

${ }^{10}$ See, for example, Hugh Aynesworth, "Bush Son Puts Hat in Ring, Admits Richards Is Liked," Washington Times, 9 Nov. 1993, A3; R. G. Ratcliffe, "George W. Bush: From the Golf Course to the Boardroom, the GOP Candidate Banks on His Desire," Houston Chronicle, 20 Oct. I 994, Voter's Guide, 9.

" James E. Garcia, "Bush Backs Home-Rule Plan for Schools," Austin American-Statesman, 22 Feb. 1994.

${ }^{12}$ Aynesworth; Stuart Eskenazi, "Bush Pitches Shutout; Anti-Democrat Fervor Helps," Austin American-Statesman, 9 Nov. 1994.

${ }^{13}$ Skip Hollandsworth, "Born to Run," Texas Monthly, 22, 5 (May 1994), i 1 2-27. In this article, Bush also stated, "'A governor can't pass a law to make you love ... But he can pass a law to protect the innocent, law-abiding citizens from thugs." This language about the inability to inculcate love through legislation appeared again during his governorship when promoting faith-based initiatives, which I address later in this essay. Given the centrality of love (or loving others as God loves) to Christianity (see, for example, I John 4:9-IO; I John 3:16), this might be read as a persistent religious trope that appeared early in Bush's political rhetoric.

${ }^{14}$ Robbie Morganfield, “Texas Governor's Race; Bush Cites Foe's 'Failed Leadership," Houston Chronicle, 4 Nov. I994, A. 
fortunes. The rift received considerable press coverage. As one Star Telegram article noted,

Civil war now looms between members of the Christian right, who generally focus on issues like abortion, and mainstream Republicans traditionally more concerned with economics ... Many mainstream Republicans view the grassroots coup with alarm and anger, although they are often reluctant to express the reactions publicly for fear of antagonizing the conservative Christians. ${ }^{15}$

Bush aimed to distance himself "from [the] battle lines of [the] state GOP's internal war," partly by striking an "accommodating stance" on abortion; he noted his acceptance of Supreme Court rulings on the issue while maintaining that as governor he would promote policies "to encourage fewer abortions." 16 Though openly pro-life, and supportive of legislation requiring parental consent for minors seeking abortions, media coverage of his responses to this issue suggests that he tried to avoid discussing his views on abortion when possible to keep from alienating voters. ${ }^{17}$

Just as he sought to downplay the divisive issues that religious conservatives within the Texas Republican party promoted, Bush also worked assiduously during the campaign to refrain from making overt references to religion, emphasizing his belief that religion and politics should not mix. He spent the Sunday before the 1994 election worshiping at his own church, rather than making the customary final campaign appearances at other churches throughout the state. After the service, he made a statement to the press about the role of religion in his life. According to the Houston Chronicle:

Bush called his own religious faith important but personal. "I've been very careful about not trying to campaign as a more godly candidate," he said. "I just don't agree with that. I don't agree with mixing religion in political campaigns ... But in my personal life and in my daily walk, my relationship with God is important. I believe in prayer. And I believe I can receive strength and sustenance from the Lord by praying to the Lord." ${ }^{8}$

Is Tim Madigan, “Christian Right Gaining Clout within GOP,” Fort Worth Star-Telegram, 5 June i 994, I, 20.

${ }_{1} 6$ “50 State Report - Texas: Dem. Convo. Pushes GOP as Party of 'Religious Right,"” National Journal Hotline, 6 June 1994; "Politics - Rightward March?" National Journal Hotline, 6 Aug. 1994.

17 “Governors '94-Texas: Richards Pushes Buttons on Abortion, Race," National Journal Hotline, 24 Oct. 1994.

${ }^{18}$ Robbie Morganfield, "Campaign '94; Governor Race Down to Wire; Confident Bush Goes to Church," Houston Chronicle, 7 Nov. 1994, Ar. Bush later stated that he avoided talk of religion because after one occasion when he discussed beliefs (relating his understanding that, according to the New Testament, God allowed only those who "accept[ed] Christ as one's savior" into Heaven) Richards "ran ads in a Jewish newspaper that pointedly stated - Bush says you cannot go to heaven," costing him votes. George W. Bush, "Commitment to the Vision," speech, Westlake Hills Presbyterian Church Congregation Banquet, Austin, TX, 3 Nov. 1996, I, Box 2002/151-67, Texas Governor George W. Bush Executive Office 
Bush thus affirmed the depth of his faith while also intimating that he honored the separation of church and state. This statement, in conjunction with his reluctance to discuss his religious beliefs during the campaign, provides a valuable benchmark for measuring how Bush's use of religious rhetoric and his conception of the relationship between faith and policy changed over the course of his political career.

Bush won the 1994 gubernatorial election by a considerable margin, and set to work immediately to achieve the conservative policy objectives he had outlined during his campaign. ${ }^{19}$ In his State of the State address to the Texas legislature in February 1995, he urged lawmakers to promote what he referred to as their shared "Texas values," which included personal responsibility, local rather than state control of schools, and strong families. ${ }^{20} \mathrm{He}$ reminded them of his commitment to tort reform, requesting that the legislature enact laws to "put a meaningful cap on punitive damages" and end "frivolous and junk lawsuits" which hampered economic development. ${ }^{21}$ Bush spoke at length about "home rule" for local school districts. He also reiterated his desire to see tough reforms to the criminal justice system, both to instill discipline and "strong values" in juvenile offenders and to ensure that violent adult offenders remained behind bars. ${ }^{22}$ Continuing along this conservative line, he called for changes to the welfare system "to encourage work and initiative" and to "break the cycle of dependency" of those seeking aid from the state by placing limits on the benefits available to them. ${ }^{23}$

Though Bush joked that reporters had grown tired of hearing him repeat these four core objectives in every speech, the clarity and framing of his legislative agenda is significant. His claim that "my guiding principle will be government if necessary, but not necessarily government," along with his emphasis on traditional (though not specifically religious) values, endeared him to Republicans as well as to conservative Democrats. ${ }^{24}$ Bush achieved considerable success in carrying out his domestic agenda, moving all four

Speeches, Archives and Information Services Division, Texas State Library and Archives Commission.

${ }^{19}$ Bush won by 350,000 votes. Paul Burka, "More Power to Him," Texas Monthly, 23, 2 (Feb. 1995), i 16.

${ }^{20}$ George W. Bush, "State of the State," State of Texas, Journal of the House of Representatives of the State of Texas, 74th Legislature, 7 Feb. 1995, 322-23. Available from www.lrl.state.tx.us/ scanned/govdocs/George\%20W\%20Bush/1995/SOS_Bush_1995.pdf.

${ }^{21}$ Ibid., 323.

${ }^{24}$ George W. Bush, "Inaugural Address," State of Texas, Journal of the House of Representatives of the State of Texas, 74th Legislature, 17 Jan. 1995, 36, available from www.lrl.state.tx.us/ scanned/govdocs/George\%20W\%20Bush/r995/IA_Bush_1.17.95.pdf. See also George W. Bush, "A Budget Policy Message to the Seventy-Fourth Legislature Assembled in Regular Session," I 5 Feb. I 995, available from www.lrl.state.tx.us/scanned/govdocs/George\% 20W\%20Bush/1995/BudgetPolicyMessageo2 I 595.pdf. 
initiatives forward within his first hundred days as governor. ${ }^{25}$ One journalist commented that Bush "was on a winning streak that seemed likely to last through the legislative session. No first-term governor in memory has had such a high batting average on issues of such importance." ${ }^{26}$ Perhaps most noteworthy, with the exception of one line in his inaugural address where he declared that the responsibilities of the governor's office "can best be met with the guidance of One greater than ourselves," nowhere in his initial public statements as governor did Bush utilize religious tropes to appeal to Texans. ${ }^{27}$ Political, rather than religious, values informed his rhetoric in his first term as governor.

So, too, did achieving his conservative aims through bipartisan cooperation, an effort that reflected the political sympathies of Texans in the mid-r 990 as well as the relative lack of power that Texas governors held over the legislature. ${ }^{28}$ During his first term, Bush had to work closely with Democratic Lieutenant Governor Bob Bullock in order to succeed in achieving his legislative agenda. In early 1996, U.S. News and World Report wrote that Bush, with the support of Bullock and Democratic Speaker of the House Pete Laney, had "passed a school-reform bill that removed most state controls on local districts, a welfare reform measure that allowed greater local innovation, a juvenile-justice law with tougher sentencing and a tort-reform bill changing the rules that made Texas a trial lawyer's paradise," all while keeping spending and taxes low. ${ }^{29}$ Although his policies as governor fell squarely within conservative political orthodoxy, Bush broke somewhat with national Republican ideology in seeking to foster trade with Mexico and adopt moderate immigration policies. ${ }^{30}$ In this manner, he continued

${ }^{25}$ R. G. Ratcliffe, “Away from the Spotlight, Governor Makes His Mark," Houston Chronicle, I 5 Apr. I995, Ai.

${ }^{26}$ Paul Burka, "Four for Four," Texas Monthly, 23, 6 (June 1995), io6.

${ }^{27}$ Bush, "Inaugural Address," 35. That said, in its coverage of the inaugural address, the Houston Chronicle did include a quote from an interview with Bush in which he stated that he intended "to be part of a catalyst for cultural change," which the reporter interpreted as evidence that Bush's focus on personal responsibility signified his belief that "God and government help those who help themselves." R. G. Ratcliffe, "Bush Aims to be Catalyst for Wide Cultural Change," Houston Chronicle, is Jan. I995, A.

${ }^{28}$ On the political leanings of Texans during Bush's campaign for and first term as governor see Lois Romano and George Lardner Jr., "Bush's Move up to the Majors," Washington Post, 3 I July 1999, Ar; on Texas's constitutional limits to the power of the governor see McCall, The Power of the Texas Governor, 132.

${ }^{29}$ Michael Barone, "Best Little Governor in Texas," U. S. News and World Report, I Jan. 1996.

${ }^{30}$ Bush viewed Mexico as "'crucial' to the Texas economy," and sought to improve business relations between the two countries, while also adopting "a strict stand on border enforcement but a compassionate, or at least pragmatic, view of those who slip through." Indeed, when President Bill Clinton met with the nation's governors in January I 995 to garner support for his proposal to rescue the ailing Mexican economy through a federal loan 
his efforts to appeal to the Texas Republicans, conservative Democrats, and independent voters who had elected him governor by focussing narrowly on state issues. ${ }^{31}$ Yet by January 1997 reporters had begun to proclaim that "the honeymoon" between Bush and his erstwhile Democratic partners "is definitely, irrevocably, terminally over." ${ }^{32}$ His legislative victories had sown the seeds of discontent.

Bush's success in enacting the conservative policies he promoted in his gubernatorial campaign also garnered him attention nationally as a potential Republican nominee for the year 2000 presidential election. ${ }^{33}$ Aware of this, Bush developed his agenda for the 1997 Texas legislative session with an eye toward attracting GOP support, focussing his attention on tax reform and faith-based initiatives. ${ }^{34}$

The salience of these issues in national politics, and, therefore, in the matrix of calculations for a presidential run, reflected the Republican Party's success by the mid-I990s in building public support for limited government and in "capitaliz[ing] on concerns in large sectors of society about changing social and sexual mores." 35 This ideological shift, along with conservative coalition-building efforts that included the cultivation of the religious right as a reliable voting bloc, contributed to the Republican Party's dramatic return to Congressional power in $1994 .^{36}$ Furthermore, although scholars have

guarantee, Bush jumped to his defense. Despite outcry from Republicans outside Texas, Bush expressed concern that without the loan guarantee the value of the peso would decline, hurting the Texas economy and potentially leading to increased illegal immigration. See Scott Pendleton, "Stetson-Size Agenda for Texas," Christian Science Monitor, I 5 Dec. 1994, 2; "Mexico/Aid/Clinton," NBC Evening News, 20 Jan. 1995, Vanderbilt Television News Archive, available from http://tvnews.vanderbilt.edu/program.pl?ID=602688; "Buchanan: Gets a Strong Warning from George W. Bush," National Journal Hotline, 16 Aug. 1995.

${ }^{31}$ Pendleton, 2.

${ }^{32}$ Paul Burka, "The Honeymoon Is Over," Texas Monthly, 25, I (Jan. 1997), I 34.

${ }^{33}$ Ibid.

${ }^{34}$ Gregory Curtis, "Scattered Applause," Texas Monthly, 25, 3 (March i 997), 7; McCall, I 24.

${ }^{35}$ Nicol C. Rae, Conservative Reformers: The Republican Freshmen and the Lessons of the 104th Congress (Armonk, NY: M. E. Sharpe, 1998), 209-10. Rae argues that "by the early I990s, the conservative critique that [the] incremental expansion of government [over the previous forty years under Democratic Congressional control] was largely responsible for ballooning federal deficits had become conventional wisdom among the public." He also notes that Republicans made political hay of the moral and ethical scandals that plagued Democrats this period.

${ }^{36}$ Julian Zelizer suggests that these efforts revealed the fits and starts of conservative realignment and power in Congress in the I9905, and highlights tensions between conservative factions within the Republican Party. Zelizer, "Reflections," 373-75. On conservatism and the Republican Revolution in 1994 see Critchlow, The Conservative Ascendancy, 22 I, 240-43, 254-77; Daniel J. Balz and Ronald Brownstein, Storming the Gates: Protest Politics and the Republican Revival (Boston: Little, Brown, 1996); Rae, 27-61; John J. Coleman, "Clinton and the Party System in Historical Perspective," in Steven E. Schier, ed., The Postmodern Presidency: Bill Clinton's Legacy in U.S. Politics (Pittsburgh: University of 
downplayed the influence that Newt Gingrich's Contract with America had on voters in the 1994 midterm elections, the issues that Gingrich emphasized as Speaker of the House reinvigorated the Republican base and helped the party navigate long-standing tensions between fiscal and social conservatives. ${ }^{37}$ Yet the Republican revolution did more than just reify tax cuts and small government as conservative orthodoxy. As part of a plan to cut welfare programs, Gingrich introduced Congress to the work of University of Texas journalism professor Marvin Olasky, who advocated private and faith-based initiatives to provide social services to the poor. ${ }^{38}$ Olasky proved profoundly influential in shaping Bush's thinking about welfare reform in Texas and in the development of his "compassionate conservative" political philosophy. 39 The ascendancy of conservative Republicans in Congress and the injection of their ideology into public discourse primed Bush and other Republican

Pittsburgh Press, 2000), I 45-66, I 5 I-52. On the conservative realignment and the religious right see D. Michael Lindsay, "Ties That Bind and Divisions That Persist: Evangelical Faith and the Political Spectrum," American Quarterly, 59, 3, Religion and Politics in the Contemporary United States (Sept. 2007), 90 I-2; Wade Clark Roof, "American Presidential Rhetoric from Ronald Reagan to George W. Bush: Another Look at Civil Religion,” Social Compass, 56, 2 (2009), 286-301, 299.

${ }^{37}$ Zelizer, "Reflections," 373-75; Rae, 59-6r; Randall Strahan and Daniel J. Palazzolo, "The Gingrich Effect," Political Science Quarterly, I19, I (Spring 2004), 89-1 I4; Gary C. Jacobson, "The 1994 House Election in Perspective," Political Science Quarterly, i I (Summer 1996), 203-23; Paul Frymet et al., "Party Elites, Ideological Voters and Divided Party Government," Legislative Studies Quarterly, 22 (May 1997), 195-2 I 6; John B. Bader, Taking the Initiative: Leadership Agendas in Congress and the "Contract with America" (Washington, DC: Georgetown University Press, 1996), 171-205.

${ }^{38}$ In his first speech as Speaker of the House, Gingrich cited Olasky's book The Tragedy of American Compassion. In subsequent discussions of welfare reform and the Contract with America, Republicans referenced Olasky's work frequently. See Newt Gingrich, "Election of Speaker," Congressional Record, I 4 I, I (4 Jan. I995), H3; House Committee on Ways and Means, Contract with America: Overview, 104th Cong., Ist Sess., Jan. 1995; Hilary Stout, "A Texas Professor's History of Poverty Programs Has Made Him the Darling of Conservative Elite," Wall Street Journal, 20 March i995, Ai6.

${ }^{39}$ Karl Rove provided Bush with a copy of Olasky's book, and Bush and Olasky met in person and began developing a close relationship in 1995 when the two swept in to save the Christian drug rehabilitation program Teen Challenge from closure due to alleged violations of state safety codes. Olasky subsequently provided guidance to the Advisory Task Force on Faith-Based Community Service Groups that Bush set up in 1996; by 1999, Bush had appointed Olasky to chair his policy subcommittee on religion. Bush also wrote an approving introduction to Olasky's Compassionate Conservatism: What It Is, What It Does, and How It Can Transform America, published in July 2000. See David Grann, "Where W. Got Compassion," New York Times, I2 Sept. I 999; David Harris, "New Book Reveals Truth about Governor Bush, Marvin Olasky, and 'Compassionate Conservatism," PR Newswire, 23 June 2000; James Moore and Slater Wayne, Bush's Brain: How Karl Rove Made George W. Bush Presidential (Hoboken, NJ: J. Wiley, 2003), I68, I70; Aikman, $A$ Man of Faith, 100-1. 
political contenders to focus on these issues, which had demonstrated efficacy in mobilizing voters. ${ }^{4}$

While the policies that Bush pursued during his first two years as governor centered on issues that appealed to Republicans as well as to moderate and conservative Democrats, the tax plans that he unveiled in 1997 and 1999 highlighted the ideological divide between the parties and revealed Bush's mounting efforts to build up his national standing. ${ }^{41}$ In his 1997 State of the State address, Bush underscored the notable economic growth that Texas had experienced under his governorship, announcing that "we face no immediate legal or fiscal crisis." ${ }^{2}$ The state boasted a substantial budget surplus, and, as such, Bush proposed implementing "a billion dollar tax cut" to return some of this surplus to taxpayers through reduced property taxes. ${ }^{43} \mathrm{He}$ also called for a "fair and reasonable" tax on businesses to fund increased spending for education. ${ }^{44}$ In this manner, Bush drew on popular conservative economic rhetoric to promote his policies, emphasizing savings to taxpayers, friendliness to small businesses, and offsets to balance new spending. Nevertheless, the state legislature rejected most of the plan, save for cuts to property taxes. ${ }^{45}$ Media coverage of the response to his address highlighted Democratic disenchantment with Bush and his new legislative agenda. One article suggested that Democrats in the Texas House and Senate viewed his plan as a political move to position himself "to compete with other Republican governors ... who have

${ }^{40}$ Critchlow, 255. Critchlow argues that Republicans took Gingrich's successful mobilization of the party base in 1994 to heart in their strategies for the 2000 election, despite the setbacks he caused the party in 1996 and 1998 .

${ }^{41}$ Burka, "The Honeymoon Is Over," I 34.

${ }^{42}$ George W. Bush, "State of the State," State of Texas, Journal of the House of Representatives of the State of Texas, 75th Legislature, 28 Jan. 1997, I 5 I, available from www.lrl.state.tx.us/ scanned/govdocs/George\%20W\%20Bush/1997/SOS_Bush_1 997.pdf.

${ }^{43}$ Ibid., I 55 .

${ }^{44}$ Ibid. Bush referred to the proposed tax on business as "low" and "capital-friendly." His plan also included "a half-cent increase in the sales and motor vehicle tax." In his plan, these new taxes would offset the loss of funding to schools that the property tax cut would create. Democrats had hoped to use the surplus to expand state programs. According to journalist Paul Burka, by balancing increased education spending with new revenue and offering tax relief to property owners, Bush could argue that his plan provided a net tax cut to Texans, even though in reality the plan would cut taxes for some while raising them for others (as Democrats duly noted). Burka speculated that the popularity of tax relief might help Republicans win the House in 1999 too. See Burka, "The Honeymoon Is Over," I 34. Although Republicans had captured the Texas Senate in 1996, ostensibly making it easier for Bush to achieve his agenda despite the end of his "honeymoon" with Laney and Bullock, not all Texas Republicans approved of Bush's 1997 tax plan, which contributed to the challenges it faced when it came up for a vote. McCall, The Power of the Texas Governor, I 25.

${ }^{45}$ George W. Bush, A Charge to Keep: My Journey to the White House (New York: Morrow, 1999), I29. 
already cut taxes and spending in their states." 46 In $A$ Charge to Keep, Bush asserted that he had not yet begun considering a run for the presidency as of the 1997 legislative session. ${ }^{47}$ Whether or not this is true, he made tax reform a key part of his successful campaign for reelection as governor in 1998 and, in January 1999, he called on the Texas legislature to implement another $\$ 2$ billion in tax cuts. ${ }^{4}$ Six months later, Bush announced his candidacy for president. At that point, appealing to Republican voters outside Texas had become paramount, and, as journalists James Moore and Wayne Slater note, the tax agenda he laid out in 1999 had "a strong ideological bent guaranteed to find favor among Republican primary voters." 49 By publicizing his desire to use part of the state's budget surplus to provide tax relief, rather than to increase state spending as some Democrats might have preferred, Bush affirmed his commitment to pursuing conservative policies and built support within the national Republican Party. ${ }^{50}$

Although Bush's property tax relief plan attracted the most attention from the media, his proposal to reduce welfare spending in Texas by easing regulations and oversight of faith-based charities marked the beginning of a key shift in how he expressed his political philosophy publicly. In his 1997 State of the State address, Bush called for reforms "to make sure our welfare system changes behavior," but asked that new legislation do so "in a compassionate way." s I To accomplish this, Bush urged the legislators to act on the "Faith in Action" report that his Advisory Task Force on Faith-Based Community Service Groups had written in late 1996. He outlined the vision presented in the report, stating,

Many organizations in Texas, faith-based groups, want to do more to help their fellow Texans. They want to follow their hearts, but fear bureaucratic rules and regulations will stifle their souls and threaten the religious nature of their mission. Our laws and rules in Texas should encourage people to help ... ["Faith in Action"] is a blueprint that outlines how government can encourage people of faith to help people get off and

${ }^{46}$ Burka, "The Honeymoon Is Over," I 34. See also McCall, I 24. McCall makes a similar argument, noting that Republican governors and potential candidates John Engler, Christine Todd Whitman, and William Weld had already implemented tax cuts in their states, and that Bush seized on a large budget surplus to do the same in Texas.

${ }^{47}$ Bush, $A$ Charge to Keep, 223.

${ }^{48}$ George W. Bush, "State of the State," State of Texas, Journal of the House of Representatives of the State of Texas, 75th Legislature, I2 Jan. 1999, 160, available from www.lrl.state.tx.us/ scanned/govdocs/George\%20W\%20Bush/1999/SOS_Bush_1 999.pdf.

${ }^{49}$ Moore and Slater, Bush's Brain, 235. Moore and Wayne suggest that Bush aggressively pursued tax cuts in 1999 as part of a strategy directed by Karl Rove to beat out other potential Republican nominees. If nothing else, the 1999 State of the State address emphasized tax cuts, balanced budgets, and small government. See Bush, "State of the State," I60.

5o Burka, "The Honeymoon Is Over," I 34.

${ }^{51}$ Bush, "State of the State," 28 Jan. 1997, 152. 
stay off welfare. Our society faces many tough problems. It's time to seek, not shun, divine help. ${ }^{52}$

The authors of the "Faith in Action" report argued that while government should continue to provide services to the needy, it should not "cling to the statist belief that it has exclusive jurisdiction for the poor," particularly since "the faith community" had a scripturally based responsibility to "tend to people's temporal as well as heavenly needs." 53 The report suggested that faithbased organizations in Texas could address the state's most pressing social ills more effectively than could government. It argued that while the state could not change the "human character ... Some of our worst social pathologies (e.g., illegitimacy, crime, poverty) can be solved if people experience spiritual transformation." 54 The report advocated a "charitable choice" provision for the Texas welfare system, based on a similar measure that John Ashcroft had introduced and passed in the US Senate in 1996, which would allow the needy the option of receiving aid from a faith-based charity rather than a state program.55 It also called for a clause to protect the religious liberties of faithbased groups and the methods used in their programs. ${ }^{56}$

The "Faith in Action" proposal expanded Bush's commitment to conservative political principles (such as reducing dependence on stateprovided welfare) into a comprehensive vision for enacting broader cultural change. For obvious reasons, the proposal appealed to Christian conservatives. Given his political ambitions and the reality that evangelicals had made steady progress amassing political clout in the Republican Party, promoting "Faith in Action" seemed pragmatic, as it helped bridge the gap between social and economic conservative principles. In the speeches he made to churches about his efforts to pass a faith-based initiatives bill, Bush stressed his belief in the separation of church and state, much as he had during his gubernatorial campaign. ${ }^{57}$ However, in contrast to 1994 , Bush explained in greater detail the underlying philosophy behind his sentiments. His concerns about churchstate cooperation did not stem from a fear that injecting religion into politics might erode democracy. Rather, Bush stated that he valued the separation of church and state because "anytime the church enters the realm of politics the church runs the real risk of losing its mission, the teaching of the word of God."58 Furthermore, he explained that he disapproved of politicians who used their faith to cast themselves as godlier than their opponents because he

\footnotetext{
52 Ibid.

${ }^{53}$ Governor's Advisory Task Force on Faith-Based Community Service Groups, "Faith in Action ... A New Vision for Church-State Cooperation in Texas," Dec. I 996, vii, available from www.twc.state.tx.us/svcs/charchoice/faithful.pdf.

54 Ibid., 2. 55 Ibid., 4-6.

${ }^{57}$ Bush, "Commitment to the Vision," I.

${ }^{56}$ Ibid., I I.

${ }^{58}$ Ibid.
} 
viewed this as "contradictory to the teachings of the Lord." 59 According to Bush, the "Faith in Action" proposal protected the mission of the church while allowing religious groups to perform the vital services that he believed the government could not - and should not - provide.

As Bush worked to promote the Faith-Based Bill that developed out of the "Faith in Action" recommendations (Texas HB 21, HB 248 I, HB 2482, and SCR 44), his rhetoric about the proper role and capabilities of government evolved. Bush's speeches on the bill recalled, but expanded upon, statements he had made during his first gubernatorial campaign. He maintained that government had a role to play in addressing social problems, but added that the state could not provide a comprehensive solution because "government can't make people love one another ... only faith can do that." 60 At the Texas Legislative Prayer Breakfast in February 1997, Bush told lawmakers that, although he believed in the separation of church and state, "in the world of politics, it helps to be a believer, to have core convictions and principles, on which to base your decisions. And the Bible's a pretty good political handbook." ${ }^{61} \mathrm{He}$ continued by stressing that he had made it his mission as governor to harness the power of believers and their principles to solve the social ills that plagued Texas through the Faith-Based Bill. Bush told his audience,

I am convinced that to fundamentally and permanently change our culture, we must have a renewal of spirit in our country. One of the biggest challenges in our culture came when people turned away from God, and lost touch with our bedrock values that have stood the test of time: Love your neighbor. Give an honest day's work for an honest day's wages. Don't lie, cheat, or steal. Respect others, respect their opinions, respect their property. And always remember, you are responsible for what you say and what you do. ${ }^{62}$

${ }^{59}$ Ibid.

${ }^{60}$ Bush, "Commitment to the Vision," I 3 . See note 13 above. In the 1994 campaign, he did not reference faith explicitly as the solution, but simply stated that government could not make people love one another. The inclusion of religious faith as part of the solution was thus a new development (rhetorically at least) that came with this initiative. See also George W. Bush, "Talking Points," Faith-Based Bill Press Conference, Austin, TX, i I March I 997, 2, Box 2002/ I 5 - 67, Texas Governor George W. Bush Executive Office Speeches, Archives and Information Services Division, Texas State Library and Archives Commission.

${ }^{61}$ George W. Bush, "Remarks," Texas Legislative Prayer Breakfast, Austin, TX, I 3 Feb. I 997, 4, Box 2002/1 51-67, Texas Governor George W. Bush Executive Office Speeches, Archives and Information Services Division, Texas State Library and Archives Commission.

${ }^{62}$ Ibid., 16. Bush used this language, in nearly identical form, in the following speeches: Bush, "Talking Points," Faith-Based Bill Press Conference, I I March 1997; Bush, "Talking Points," Faith-Based Bill Signing Ceremony (HB 21, HB 2481, HB 2482, SCR 44), Arlington, TX, I 2 June 1997; Bush, "Remarks," National Baptist Congress of Christian Education, Houston, TX, I 7 June I 997; Bush, "Remarks," Dedication of the Power Center's Jesse H. Jones Ballroom, Houston, TX, 8 July 1997. All speeches from Texas Governor George W. Bush Executive Office Speeches, Archives and Information Services Division, Texas State Library and Archives Commission. 
This statement, while entirely in line with the core principles that Bush had advocated during his time as governor, exemplifies the transformation of his rhetoric that had occurred by the end of 1996. It reveals the clear influence of conservative intellectuals, particularly Marvin Olasky, on his thinking and shows that he, with guidance from advisers Karl Rove and Karen Hughes, leveraged the broad appeal of these views to frame his policies for maximum political return. ${ }^{63}$ The success of the bill, and the national attention that it garnered for Bush, ensured that this new faith-infused language about cultural change and "bedrock values" would become a hallmark of his future speeches and stated political philosophy.

Indeed, Bush began to incorporate the religious rhetoric that he had used to secure the passage of the Faith-Based Bill into speeches on other issues. This language, along with his legislative achievements and the "growing support among conservative circles" for the types of faith-based initiative that he had implemented in Texas, helped him amass a national political following. ${ }^{64}$ In August 1997, Bush delivered a speech entitled "The Future of America" to the Midwest Republican Leadership Conference. The speech laid out a vision for the Republican Party based on the issues he had tackled as governor. $\mathrm{He}$ stressed that all Republicans shared "a conservative philosophy that is fair and decent and compassionate," a philosophy based on fiscal responsibility and limited government. ${ }^{65}$ More significantly, he repeated verbatim the sentiments about the need for "a renewal of spirit" in America that he had expressed at the Texas Legislative Prayer Breakfast in February ${ }^{66}$ In this manner, he introduced his "compassionate conservative" political philosophy in fully developed form to a national audience, merging the conservative views he had espoused during his gubernatorial campaign with the religious rhetoric that had become so effective politically in Texas in recent months. Making this philosophy the lynchpin of his remarks at such visible and politically significant events as the

${ }^{63}$ Bush emphasized the need for cultural change and "personal responsibility" as part of his effort to cast the Clinton era as one of cultural crisis and declension; he often stated his objection to what he characterized as the "if it feels good, do it, and if you've got a problem, blame somebody else" culture of the i 990 s. Bush, $A$ Charge to Keep, 25 . On the influence of Olasky, Rove, and Hughes on Bush's thinking and strategy see Bill Minutaglio, First Son: George W. Bush and the Bush Family Dynasty (New York: Times Books, 1999), 289, 317; Gary Gerstle, "Minorities, Multiculturalism, and the Presidency of George W. Bush," in Zelizer, The Presidency of George W. Bush, 252-81, 26I. Aikman, A Man of Faith, 100-1; Aikman, "Religion and the Presidency of George W. Bush," in Gastón Espinosa, ed., Religion and the American Presidency: George Washington to George W. Bush with Commentary and Primary Sources (New York: Columbia University Press, 2009), 477-502, 487; Michelle Cottle, "The Enforcer: The Woman behind George W.'s Iron Bubble," New Republic, 29 Nov. 1999, 20-23, $22 . \quad \quad{ }^{64}$ Curtis, "Scattered Applause," 7.

${ }^{65}$ George W. Bush, "The Future of America," Midwest Republican Leadership Conference, Indianapolis, Indiana, 23 Aug. 1997, in Vital Speeches of the Day, 63, 23 (15 Sept. 1997), $733-35,733$.

${ }^{66}$ Ibid., 735. 
Midwest Republican Leadership Conference and the 1998 Republican Governors Association meeting allowed Bush to build his national reputation while avoiding other, more polarizing, conservative issues. ${ }^{67}$

Bush had incorporated Christian language into his public statements gradually and experimentally over the course of his first term as governor; the blend of evangelical rhetoric and conservative orthodoxy that had crystallized in his philosophy of compassionate conservatism by 1997 emerged only because he found that this formulation resonated with voters. In particular, Bush and advisers Karl Rove and Karen Hughes had discovered the power of faith-based initiatives and religious language to win support from African Americans and Hispanics, two groups that traditionally voted for Democratic candidates, without alienating Republicans. ${ }^{68}$ In a press conference delivered in a mix of Spanish and English after his reelection in 1998, Bush attributed his landslide victory to the broad appeal of his political philosophy, stating,

I showed Texans, I showed people who pay attention to politics, that one can adhere to the conservative philosophy and implement policies that are compassionate for our fellow Texans. I believe I showed people that you can adhere to a conservative philosophy and win a sizable portion of the Hispanic vote and close the gender gap. ${ }^{69}$

Reports from the election bore out his analysis, as "exit polls showed that Bush won 49 percent of Hispanics, up 2 I percentage points from 1994. Among women, he got 65 percent, up is points ... Bush even appealed to more black voters, jumping I 2 points to 27 percent." 70

In $A$ Charge to Keep, Bush explained his embrace of faith-based initiatives as a pragmatic response to government overreach, an example, along with the major tax cuts he implemented, of his transformative leadership in Texas. ${ }^{71}$ Clearly, promoting faith-based initiatives also paid him tremendous political dividends.

By 1998 , the media had started to speculate in earnest about his presidential ambitions. National Republican strategists, eager to avoid a repeat of the

${ }^{67}$ A number of commentators have noted that Bush zeroed in on compassionate conservatism as a way to establish his conservative bona fides without stating too forcefully his views on divisive issues, such as abortion, that might alienate independent, moderate, and Democratic voters. See Verhovek, "Is There Room," I-2; James L. Guth, "George W. Bush," I 39; Kruse, "Compassionate Conservatism," 228, 230.

${ }^{68}$ Political scientist James L. Guth notes that Bush experienced success in cultivating relationships with prominent African American pastors in Texas after 1996 because of "his evident personal faith and sympathy for their vision of a broader social role for religious institutions." Guth, I20.

69 "Bush Touts Compassionate Conservatism, Says There's A Role For Government," White House Bulletin, 4 Nov. 1998.

70 "Victories for Bush Brothers Show GOP How to Lure Voters; Texas Governor Suggests That 'Compassionate Conservatism' Is Future," St. Louis Post-Dispatch, 5 Nov. 1998, A8.

${ }^{71}$ Bush, $A$ Charge to Keep, 2 13-1 8. 
party's electoral defeat and poor performance among Hispanics, African Americans, and women during the 1996 Dole campaign, recognized Bush's potential to revitalize the image of the Republican Party. ${ }^{72}$ In addition to building new constituencies, his religious rhetoric also won him growing attention from the Christian right, a crucial Republican voting bloc. Bush recognized the political importance of maintaining and expanding his ties to the evangelical community. In an NBC Evening News report in June 1998, anchor Tom Brokaw noted that although Bush denied he had plans to seek the Republican nomination for the upcoming election, he had begun "consulting regularly with Ralph Reed, the strategist who once ran the Christian Coalition." 73 According to Brokaw, Bush said "he dismisses suggestions the GOP is tilting heavily to the Christian conservative agenda," though the change in his own political rhetoric belied this assertion. ${ }^{74}$ In interviews, Reed asserted that the eventual Republican nominee would need to "unite economic and religious conservatives" in order to win the presidency.75 Bush seems to have taken this insight to heart in his campaigns for the governorship in 1998 and for the presidency in 2000.

When Bush won the 1998 gubernatorial election with nearly 70 percent of the vote, he thanked his constituents for their support and for providing him with a mandate to continue to implement his "compassionate conservative" policies. In his election-night speech, he promised,

I will continue to work to change our culture from one that has said if it feels good do it and blame someone else if you have a problem, to a new culture where every Texan understands that each of us must be responsible for our actions, our families, and for loving our neighbors as we would like to be loved ourselves. ${ }^{76}$

This speech repeated the rhetoric about cultural change, personal responsibility, and the golden rule that had become his standard talking points by late 1998. Expanding upon these points in his inaugural address, Bush alluded to Genesis when he explained that "all of us have worth. We're all made in the

${ }^{72}$ Nicol C. Rae, "The George W. Bush Presidency in Historical Context," in Schier, High Risk and Big Ambition, 17-36, 3 1, 34; Amy E. Black, Douglas L Koopman, and David K. Ryden, Of Little Faith: The Politics of George W. Bush's Faith-Based Initiatives (Washington, DC: Georgetown University Press, 2004), 78-83; Wells and Cohen, "Keeping the Charge," I 44-45. This, indeed, became a key part of Bush and Rove's strategy in the 2000 election. See Frank Bruni, "Bush Sends 2 Signals in Minority Contacts: Political Memo Minority Voters Dot Bush’s Campaign Calendar," New York Times, i 8 Oct. I999, Ai, Ar 9.

73 "Texas/George W. Bush," NBC Evening News, I 7 Jun. 1998, Vanderbilt Television News Archive, available from http://tvnews.vanderbilt.edu/program.pl?ID $=624757$.

${ }^{74}$ Ibid.

${ }^{75}$ Jill Lawrence, "Ralph Reed Heeds a New Political Calling," USA Today, I 4 April i998, 8A.

${ }^{76}$ George W. Bush, "Election Night," Election Night Celebration, Austin, TX, 3 Nov. I 998 , 7 , Box 2002/15I-169, Texas Governor George W. Bush Executive Office Speeches, Archives and Information Services Division, Texas State Library and Archives Commission. 
image of God," and, with the help of "decent, caring people who heard the call to love their neighbors as they would like be loved themselves," all citizens "have an equal chance to succeed." $77 \mathrm{He}$ added that democracy could not flourish without "educating our children about their moral and civil responsibilities," which included living by the Christian values he promoted, explicitly, in this inaugural address. ${ }^{78}$ Bush concluded by declaring, "My fellow Texans, as we head into a new century, Texas lives on the sunrise side of the mountain," an obscure biblical reference he would repeat again and again in later speeches. ${ }^{79}$ Bush thus used the 1999 inaugural address as an opportunity to begin to incorporate scriptural references into his political philosophy.

Intending to build on the success he had experienced in his first term by focussing on similar core issues, Bush made tax cuts and the passage of the Texas Religious Freedom Restoration Act, which complemented the FaithBased Bill, major legislative priorities for his second term. ${ }^{8 \circ}$ In introducing the Religious Freedom Act, Bush announced, "One of my missions as Governor is to help foster an environment where people of faith and goodwill can express their faith and love their neighbors without fear of government intrusion or intervention." ${ }^{1}$ After reiterating these sentiments at the Faith, Family, and Freedom Conference at the Great Hills Baptist Church in March I 999, Bush celebrated the progress he had made in promoting faith-based initiatives, claiming, "faith is changing Texas. Little armies of compassion are transforming our state one heart, one soul and one conscience at a time." ${ }^{2}$

${ }^{77}$ George W. Bush, "Inaugural Address," State of Texas, Journal of the House of Representatives of the State of Texas, 76th Legislature, I9 Jan. 1999, I37, available from www.lrl.state.tx.us/ scanned/govdocs/George\%20W\%20Bush/r 999/IA_Bush_1.19.99.pdf.

${ }^{78}$ Ibid., 138 .

${ }^{79}$ Ibid., I39. Bush notes that he first read the phrase "living on the sunrise side of the mountain" in the writing of his friend Tom Lee; Episcopal Minister Frederick Stecker has suggested that this phrase is an "oblique reference to Jesus' resurrection." See Frederick Stecker, The Podium, the Pulpit, and the Republicans: How Presidential Candidates Use Religious Language in American Political Debate (Santa Barbara, CA: Praeger, 20II), 58. It is perhaps a reference to Acts I:9-I2, which suggests that Jesus ascended to Heaven from the Mount of Olives, a mountain to the east of Jerusalem's Old City, and Matthew 28, which links the dawn or sunrise and the resurrection.

${ }^{80}$ Bush, "Election Night," 4; Bush, "Remarks," Texas Religious Freedom Restoration Act News Conference, TX, i I Jan. I 999, I-3, Box 2002/i 51-169, Texas Governor George W. Bush Executive Office Speeches, Archives and Information Services Division, Texas State Library and Archives Commission; George W. Bush, "State of the State" State of Texas, Journal of the House of Representatives of the State of Texas, 76th Legislature, 27 Jan. 1995, I60-6 I, I64, available from www.lrl.state.tx.us/scanned/govdocs/George\%20W\%20Bush/ı 999/SOS_ Bush_1999.pdf.

${ }^{81}$ Bush, "Remarks," Texas Religious Freedom Restoration Act News Conference, 3.

${ }^{82}$ George W. Bush, "Remarks," Faith, Family, and Freedom Conference at Great Hills Baptist Church, Austin, TX, I Mar. 1999, 20. He repeated this speech several days later: George W. Bush, "Remarks," Second Baptist Church Services, Houston, TX, 6-7 Mar. 1999. Both 
The repetitive nature of his speeches speaks to the extent to which these tropes had shaped and gradually transformed his public political philosophy and image by 1999. This, in conjunction with the increasing frequency with which he utilized specific scriptural references, indicates that Bush recognized the political appeal of this type of rhetoric, and made use of it to advance his career. This is not to suggest that he lacked a genuine faith in Christianity. Rather, based on the care he took in his first run for governor to avoid discussing his evangelicalism, it seems his willingness to inject faith into his policies varied depending on the direction of political winds and the growing power of evangelical Christians within the Republican Party.

The fact that, after announcing his intention to seek the Republican nomination in March 1999, Bush began to share his previously undiscussed salvation experience in his speeches and writing provides further evidence that, by 1999, he saw the political utility of connecting with the evangelical Republican base. Indeed, in both of his memoirs ( $A$ Charge to Keep and Decision Points), Bush devotes several pages to describing the spiritual rebirth he experienced between 1985 and 1986 , which he depicts as an awakening that transformed his life and his outlook entirely..$^{83}$ The experience of personal salvation is a fundamental part of evangelical Christianity, and sharing the story of one's salvation plays an important role in the process of spreading the gospel and inculcating faith. Perhaps because of this, most salvation narratives share common tropes and follow prescribed patterns. ${ }^{84}$ In his memoirs, Bush's description of his tortuous road to finding Jesus fits the archetypal salvation narrative. He cites his days of hard drinking as his low point, then describes a dinner with evangelist Billy Graham as the key event that "planted a mustard seed in my soul" and led to his redemption. ${ }^{85}$ Yet David C. Bailey has argued that the narrative Bush provides in $A$ Charge to Keep is a highly modified version of his actual salvation experience, and that as such it demonstrates

Box 2002/151-169, Texas Governor George W. Bush Executive Office Speeches, Archives and Information Services Division, Texas State Library and Archives Commission.

${ }^{83}$ Bush, $A$ Charge to Keep, 135-39; Bush, Decision Points (New York: Crown Publishers, 2010), 30-34. On page x of the foreword, Bush notes that the title of $A$ Charge to Keep "is based upon a hymn written by Charles Wesley, 'A Charge to Keep I have." The hymn itself is a reference to Leviticus 8:35.

${ }^{84}$ The theological tropes vary somewhat by denomination, but the basic structure of the salvation narrative is remarkably similar. See Gerald Peters, The Mutilating God: Authorship and Authority in the Narrative of Conversion (Amherst: University of Massachusetts Press, 1993), 3-5; Elaine J. Lawless, "Rescripting Their Lives and Narratives: Spiritual Life Stories of Pentecostal Women Preachers," Journal of Feminist Studies in Religion, 7, I (Spring I 99 I), 53-71, 59; Harvey Gallagher Cox, Fire from Heaven: The Rise of Pentecostal Spirituality and the Reshaping of Religion in the Twenty-First Century (Reading, MA: Addison-Wesley Publishers, 1995), 163.

${ }^{85}$ Bush, $A$ Charge, I35-39. A reference to the Parable of the Mustard Seed (and the way Christianity spreads). 
Bush's calculated efforts during his first presidential campaign to appeal to evangelical voters and signal his "divine commission" to run for President. ${ }^{86}$ Indeed, newspaper articles from his first gubernatorial campaign that discuss his decision to quit drinking do not even mention his Christianity or salvation experience as an impetus for the decision. ${ }^{87}$ This is significant as it lends credence to the idea that Bush began to incorporate religious tropes into his public speeches strategically. ${ }^{88}$ Furthermore, given the strategic release of the book as a campaign tool, Bush's presentation of his salvation experience demonstrates that he and his advisers recognized the need to secure evangelical support in order to win the presidency.

Even after George W. Bush officially announced his intention to seek the Republican nomination to run for President, he still had to work hard to convince the most conservative members of the party that he would represent their interests. Though he marketed himself as an evangelical Republican who would stick to "core conservative principals," some worried that he might be too moderate in his views. ${ }^{89}$ For example, though pro-life, some of his stances on abortion policy raised concerns. As one reporter noted, when "Bush said there will be no litmus test on abortion, meaning, he might appoint pro-choice judges to the Supreme Court. Conservative rivals pounced." 90 His reluctance to define a clear platform until late in the nominating process may have contributed to these concerns, though it did not stop Bush from emerging as the clear front-runner, or from raising substantially more money than any other potential nominee raised. Indeed, holding off on announcing his platform made good political sense. As another reporter noted, "in truth, Bush's basic positions are well known: he's a tax-cutting, anti-abortion, probusiness, pro-school vouchers conservative. A compassionate conservative, as

${ }^{86}$ David C. Bailey, "Enacting Transformation: George W. Bush and the Pauline Conversion Narrative in A Charge to Keep," Rhetoric \& Public Affairs, I I, 2 (2008), 2 I 5-41, $216,224$.

${ }^{87}$ Ratcliffe, "George W. Bush," 9.

${ }^{88}$ So too do secretly taped conversations between Bush and his friend Doug Wead, who later published a book based on the tapes. A New York Times article described some of these conversations, including one in which, "preparing to meet Christian leaders in September I 998, Mr. Bush told Mr. Wead, 'As you said, there are some code words. There are some proper ways to say things, and some improper ways.' He added, 'I am going to say that I've accepted Christ into my life. And that's a true statement' ... Mr. Bush also repeatedly worried that prominent evangelical Christians would not like his refusal 'to kick gays.' At the same time, he was wary of unnerving secular voters by meeting publicly with evangelical leaders." David D. Kirkpatrick, "In Secretly Taped Conversations, Glimpses of the Future President," New York Times, 20 Feb. 2005.

89 "Campaign 2000/Bush," CNN Evening News, 7 March 1999, Vanderbilt Television News Archive, available from http://tvnews.vanderbilt.edu/program.pl?ID=42990 I.

90 "In Depth (Campaign 2000/Bush Candidacy)," NBC Evening News, I 4 June 1999, Vanderbilt Television News Archive, available from http://tvnews.vanderbilt.edu/program. pl? ID $=629994$. 
he likes to say." 91 B By refraining from providing too many details, he managed to garner the support of moderates in both parties, emerging as a candidate that Republicans believed would unite and expand their party and retake the White House. ${ }^{92}$

Interestingly, when Bush finally did outline his political priorities in the Republican debates, he did not utilize much religious rhetoric to promote his policy proposals. He selected a handful of core issues to focus on, including education, trade, faith-based initiatives, social security, and tax reform, much as he had during his first run for governor. ${ }^{93}$ On foreign policy, Bush sought to make up for serious gaffes he had made in early public statements by attempting to portray himself "as a clear-eyed realist, rejecting 'the blinders of isolationism,' and warning that Russia and especially China, with its increasing military strength, are potential enemies, who Bush said must be treated as looming rivals, not friends." 94 In discussing domestic issues, Bush emphasized his record as governor, citing his support for "home rule" of local schools and asserting that, as President, he would "encourage faith-based institutions and organizations that help people in need," just as he had in Texas.95 Yet, at least in this debate, he did not utilize the tropes about faith-based initiatives that he had relied on during his terms as governor. Republican strategists hoped that focussing on faith-based initiatives in this way would help the party pick up crucial independent and minority voters. ${ }^{96}$

Still, when addressing religious voters, rather than a national audience, Bush reverted to using faith-based rhetoric to garner support. In a speech at the Road to Victory conference of the Christian Coalition, Bush stressed that his compassionate conservative agenda included a strong opposition to abortion, as well as deep desire to help the less fortunate. ${ }^{97} \mathrm{He}$ also noted that

91 "Campaign 2000/Iowa/Straw Poll/Republicans/Bush," NBC Evening News, I 4 Aug. I999, Vanderbilt Television News Archive, available from http://tvnews.vanderbilt.edu/program. pl? ID $=630790$.

${ }^{92}$ Ibid. An essential strategy given that conservatives and evangelicals did not represent a large enough portion of the party to ensure a victory for Bush; he needed to attracted broad-based Republican support to win the nomination.

93 "Republican Presidential Candidates Debate," CNN, 9 Dec. 1999, Vanderbilt Television News Archive, available from http://tvnews.vanderbilt.edu/program.pl?ID $=724605$.

94 "Campaign 2000 (Bush/Foreign Policy)," NBC Evening News, I9 Nov. I 999, Vanderbilt Television News Archive, available from http://tvnews.vanderbilt.edu/program.pl? $\mathrm{ID}=62768 \mathrm{I}$. See also "Campaign 2000 (Bush: Interview and New Hampshire Primary)," NBC Evening News, 2 I Nov. 1999, Vanderbilt Television News Archive, available from http://tvnews.vanderbilt.edu/program.pl?ID $=627709$.

${ }^{95}$ Ibid.

${ }^{96}$ See notes 67 and 68 above.

${ }^{97}$ George W. Bush, "Christian Coalition Introduction," Road to Victory Conference, Washington, D. C., I Oct. I 999, 3, Box 2002/1 51-170, Texas Governor George W. Bush Executive Office Speeches, Archives and Information Services Division, Texas State Library and Archives Commission. 
"sometimes the influence of faith is ignored or dismissed. Sometimes, in our society, it seems like a weak flame in a strong wind. In reality, it is the 'shadow of a mighty rock in a weary land." ${ }^{8} 8$ Returning to familiar rhetorical territory, he reminded supporters of faith-based initiatives that "individuals are responsible to love our neighbors as we want to be loved ourselves," because government did not have the capacity to solve the social ills that plagued American society.99 Senator John McCain, a fellow contender for the Republican nomination, criticized Bush for seeking the support of well-known evangelical leaders Pat Robertson and Jerry Falwell (whom he referred to as the "Agents of Intolerance"), accusing him of pandering to the religious right. ${ }^{100}$ Evangelicals reacted angrily to McCain's denunciations, which contributed to his undoing as a potential candidate. ${ }^{\text {IOI }}$ Bush, on the other hand, received a considerable boost from evangelicals, in part because they identified deeply with his religious and cultural cues. ${ }^{102}$

Despite criticism from his opponents, Bush secured the Republican nomination and, after a divisive and contested general election, the presidency. ${ }^{103}$ In the campaign against $\mathrm{Al}$ Gore, Bush doubled down on his compassionate conservative rhetoric, hoping that this would gain him allegiance from Hispanic, African American, and conservative Christian and Catholic voters. ${ }^{104} \mathrm{He}$ and Gore alike latched on to faith-based initiatives in order to appeal to swing voters. ${ }^{105}$ This, according to scholarship on the campaign, highlighted key changes in the American political landscape by the year 2000, specifically growing disillusionment with the ability of the government to effect change, increased acceptance of religion in the public square, and the electorate's focus

${ }^{9}$ Ibid., 5.

${ }^{99}$ George W. Bush, “The Duty of Hope," Draft \# I I, The Front Porch Alliance, Faith-based Initiative, Indianapolis, IN, 22 July I 999, 5, Box 2002/151-70, Texas Governor George W. Bush Executive Office Speeches, Archives and Information Services Division, Texas State Library and Archives Commission.

${ }^{100}$ Brian Knowlton, “Republican Says Bush Panders to the 'Agents of Intolerance': McCain Takes Aim at Religious Right," New York Times, 29 Feb. 2000.

${ }^{\text {Iо }}$ Michelle Cottle, "Campaign Journal: More Like Us," National Review, 20 March 2000,

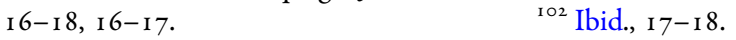

${ }^{103}$ This boost allowed him to take the Republican nomination, but did not give him enough of an edge to win the popular vote in the presidential election. Karl Rove and other Bush strategists posited that low turnout among evangelical voters contributed to this discrepancy. Bush would go to great lengths in his 2004 reelection campaign to ensure that evangelicals went to the polls. "Evangelicals Urged to Vote and 'Shape Public Policy," Washington Times, 22 June 2004. See also Robert Wuthnow, Boundless Faith: The Global Outreach of American Churches (Berkeley: University of California Press, 2009), I 93.

${ }^{104}$ Smith, Faith, 372; Guth, "George W. Bush," I 20-2 I; Black, Koopman, and Ryden, Of Little Faith, 78-80, 87; Rae, "George W. Bush," 3 I-34.

ros Jacob S. Hacker, "Faith Healers," New Republic, 28 June i 999, I6-i 8. 
on social issues. ${ }^{106}$ The latter two developments had grown out of the rise of the religious right as a political force beginning in the $19805 .{ }^{107}$ Although Bush lost the popular vote, he and his advisers believed that continuing to build and sustain ties with conservative Christians had paid off politically, and would continue to do so. ${ }^{108}$ The devout Christian and compassionate conservative political identity that Bush had crafted gradually over the course of his governorship became one of the defining elements of his presidency.

On the whole, the speeches and public statements that George W. Bush gave while running for and serving as governor of Texas, as well as while running for the presidency, reveal that his use of religious rhetoric evolved over time. Though he largely avoided discussing religion during his first gubernatorial campaign, he grew progressively more comfortable referencing his faith when discussing policy, particularly after announcing his desire to promote faith-based initiatives in 1996. For the most part, he relied on a small set of interrelated tropes to explain and gain support for his policies. For Bush, the dignity and value of every human life, each created in God's image, necessitated that individuals love one another as they want to be loved themselves. Bush's "compassionate conservative" philosophy - including his emphasis on personal responsibility and the desirability of having faith-based charities, rather than the state, provide care to the needy - emerged from these core tropes. Thus long before he became President, religious rhetoric shaped Bush's political thought and speeches.

That said, few of the tropes that Bush utilized in speeches prior to his presidency took on the messianic and crusading tones of his rhetoric after 9/I I. Although during the Republican debates in 1999 Bush did state that "our nation's greatest export to the world has been, is, and always will be [our] incredible freedoms," he did not link this sentiment with his religious beliefs in any clear or explicit manner. Nor did he discuss the concept of "freedom" in this sense much (if at all) during his two terms as governor. Bush's rhetoric about "freedom" as God's gift to the world, and about the corresponding responsibility of the United States to spread democracy abroad, appeared suddenly after the terrorist attacks of $9 / \mathrm{I}_{\mathrm{I}}{ }^{\mathrm{I} 09}$ This is not to say that the links he drew between freedom and Christianity have no roots in Scripture or in American religious history. As Robert Wuthnow notes, "the emphasis on freedom in American Christianity derives from the gospel's assertion that following Christ makes one spiritually free. A redeemed person is a liberated person." I10

\footnotetext{
${ }^{106}$ Black, Koopman, and Ryden, 75-87; Guth, I 22-I 28; Rae, 3 I-34.

${ }^{107}$ Even though, as Kevin Kruse has noted, the political power and presence of the religious right may have begun to wane in the I990s. Kruse, "Compassionate Conservatism," 227-28.

${ }^{108}$ See note 104. $\quad{ }^{109}$ Wuthnow, Boundless Faith, $200 . \quad{ }^{10}$ Ibid.
} 


\section{Lauren Frances Turek}

Although Bush did not draw on this connection between Christian beliefs and the American concept of freedom prior to 200I, it is possible that his experiences as governor, incorporating religious rhetoric into his political philosophy and forging connections with religious leaders, shaped his response to $9 / \mathrm{I}$. His deep personal faith and comfort with utilizing religious tropes to explain his political agenda may help to illuminate why he latched onto faith-based language when reaching for a way to understand and describe the new world that he believed the United States faced on I 2 September 200 I. Ultimately, it is the salience of religion and religious language in American politics in this period and the Republican Party's desire to capture new constituencies that best explains Bush's embrace of Christian rhetoric during his campaigns and presidency. Bush had evinced a deep and genuine evangelical faith for years before he launched his bid for governor, yet at the start of his political career he downplayed the role that religion played in shaping his views and policy agenda. As Republicans at the state and national levels struggled to meld the competing interests of different conservative factions and independent voters, Bush found success governing Texas by doing just that. Over time, he discovered that cloaking his conservative economic values with compassionate religious language gave him a political edge in Texas, allowing him to win substantial support among minorities, women, and conservative Democrats. By 1998, he had recognized the potential that this rhetoric had to make the GOP a "big-tent" party, and carried that realization with him to the White House. 